\title{
The Establishment of The New Environment of Mangkunegaran Sugar Industry in 1861-1942 and Its Impacts to The People's Health
}

\author{
Wasino Wasino ${ }^{1}$, Fitri Amalia Shintasiwi ${ }^{2}$, Endah Sri Hartatik ${ }^{3}$ \\ \{wasino@mail.unnes.ac.id ${ }^{1}$, shintasiwi@mail.unnes.ac.id ${ }^{2}$, hartatikendah67@gmail.com² ${ }^{2}$, \\ History Department, Universitas Negeri Semarang ${ }^{1}$, Social Science Education, Universitas Negeri \\ Semarang $^{2}$, History Department, Diponegoro University ${ }^{3}$
}

\begin{abstract}
In 1861, the sugar industry belonging to Mangkunegaran Palace, Surakarta, was established. The sugar industry was named the Colo Madu Sugar Factory located in Krambilan Village, Malang Jiwan District, Mangkunegaran City. Today, this area belonged to Karang Anyar Regency. The village was initially rice fields and the place of sugar industry in Java made from coconut. In 1881, the second sugar industry was established in the eastern part of the Mangkunegaran palace named Tasik Madu. The area was originally the rice fields, and rice was its primary crops. Thus, together with the establishment of sugar factory, the infrastructures for sugar industry was also established. This article discusses the formulation of the new environment related to the operation of sugar industry. The research used historical method by geographical approach. The results of this study show that after the sugar factory was operated, the new city was also established. The areas included factory environment, sugarcane plantation environment, irrigation systems, settlements, and transportation networks. The settlement environment created places' name which depicted the functions of each location related to the sugar factory. Moreover, the factory environment was increasingly dense, then resulted in poor sanitation which led to bubonic plague in the second decade of 20th century. Hence, the policy to improve the sanitation by Mangkunegaran government was made to prevent various diseases related to the poor environment.
\end{abstract}

Keywords: sugar industry, rice fields, settlement, environment, decrease.

\section{Introduction}

The sugar industry started to be built since the beginning of the 18th century in the Batavia region (Jakarta) [1]. When Java Island was officially controlled by the Dutch colonial government at the beginning of the nineteenth century, sugar industry remained a priority. The industry was developed by Dutch private companies [2]. The sugar industries are generally built by Dutch capital owners. The carrying capacity of the sugar industry is sugar cane. This plant is planted in areas adjacent to the location of the sugar industry or still within the range of transportation developed by the sugar industry. One of the most important areas in sugar industry investment is 
autonomous region (principalities), Surakarta and Yogyakarta [3]. In Surakarta, the land used to plant sugar cane was obtained by renting the land owned by noblemen and royal officials. They are the owners of the appanage (land borrowed from the king as the wage) [4] .

Since 1830 to 1870 , forced cultivation system was applied in almost the majority of land in Java Island. In this economic system, all sugar industries and sugar cane were controlled and cultivated by the country [5]. However, it cannot be applied in the areas of Surakarta Residency because the lands in this area were the autonomy of Sunan and Mangkunegara. That is why the management of sugar and sugar cane plants in this area was not in the hands of the Dutch Colonial Government.

In the map of the competition for ownership and control of the sugar industry in Surakarta, another sugar industry was also established by the royal family, the Mangkunegaran Sugar Industry. There are two sugar industries in Mangkunegaran namely, Colo Madu Sugar Factory which was established in 1861 in Malang Jiwan District, Kota Regency and Tasik Madu Sugar Factory in Tasik Madu District, Karang Anyar Regency which was founded in 1871. The Mangkunegaran Sugar Factory was established in a rural area where the community originally lived from the food agriculture sector, especially rice. To support the existence of the sugar factory, a number of supporting infrastructures were built starting from factory installations, highways, railways, settlements, and settlement facilities which resulted in changes in the environment and health of the local community.

In the map of competition for ownership and control of the sugar industry in Surakarta, another sugar industry was also established by royal family, namely Mangkunegaran Sugar Industry. There were two sugar industries in Mangkunegaran, namely Colo Madu Sugar Factory which was established in 1861 in the area of Malang Jiwan District, Kota Regency, and Tasik Madu Sugar Factory in Tasik Madu District, Karang Anyar Regency which was established in 1871 [6]. The Mangkunegaran Sugar Factory was established in rural area where the people initially lived from food agriculture sector, especially rice. To support the existence of the sugar factory, a number of supporting infrastructures starting from factory installation, road, railway, settlement, and the facilities for the settlement which lead to the changes in the environment and in the health of the local community [7].

\section{Research Methods}

This research of this study used historical method. Written sources were collected from Mangkunegaran Library and archives. Oral sources and archeological sites were collected from the location of Sugar Factory surroundings. Based on the Critical sources, interpretation of the relation was made between the historical facts, and finally historiography was created related to the establishment of Mangkunegaran Sugar Industry at the Colonial era. 


\section{The Results of the Study}

Based on the search of historical data, it shows that with the establishment of Mangkunegaran Sugar Factory, a new environment was created, from food agriculture-based environment to plantation industry-based environment. If previously the center of the settlement was in villages related to rice and secondary crops, then with the establishment of the factory, a new environment with sugar factory as the center of it was created.

Colo Madu Sugar Factory located in Krambilan Village, Malang Jiwan District, has become the center of the settlement and business which became the trigger of economic development in Surakarta and its surrounding areas. Likewise, Tasik Madu Sugar Factory located in Sondokoro, Karang Anyar District, also has become the trigger of the development of Karang Anyar city and the economic development in Karang Anyar Regency and its surroundings [8].

Sugar industry is supported by management level settlement centers to factory workers. Settlements related to factory management are in the factory environment followed with modern residential facilities and infrastructure such as roads, clean water, polyclinics, schools, sports facilities, and so forth. Meanwhile, factory workers' settlement is located in an environment which is very close to the factory known as Lengkong. The third environment is villages which are located outside the factory and inside sugar cane plantations. Most of the villages are old villages, and some are new villages that emerge due to the importance of opening new fields for the benefit of rice farming and sugar cane plantations. The settlements around the factory and the settlements around sugar cane plantations are connected through village roads and factory railroads known as lorry. In the environment of those two factories owned by Mangkunegaran family, a new city has been formed, a satellite city of Sala City which is located in the middle of Colo Madu and Tasik Madu sugar factories [9].

The sugar industry and residential settlements are connected by transportation routes. In the nineteenth century, horses, dokar and cikar were used as transportations which went through the village streets. However, in the 20th century, apart from those traditional transportations, new fleet of modern transportations emerged, namely automobile, trucks and buses. Besides that, there was lorry which was used to transport sugarcane stems from sugar cane plantations to sugar factory and trams which were used to transport people from Tasik Madu to Boyolali through Colo Madu Sugar Factory area. From the sugar factory area, there was a railroad link that connected it to the nearest train station for the purpose of transporting sugar produced in the Mangkunegaran sugar factory and which will be exported overseas through the Tanjung Emas Port, Semarang.

With regard to the importance of sugar factory, irrigation networks and facilities were built. Water network was really needed for the importance of sugar cane planting. Initially, the irrigation facilities of Colo Madu Sugar Factory used water from Bengawan Solo River and surrounding water sources, mainly from Boyolali Regency. Meanwhile, Colo Madu Sugar Factory used the streams of water originating from Mount Lawu. In line with the expansion of the production of those two sugar factories, a number of new irrigation facilities were built in the early twentieth century. In the area of Colo Madu Sugar Factory, a number of dams were built, namely Kemantren Dam, Brajan Dam, Pingin Dam, Tambak Bandung Dam, and Cengklik Reservoir. Among those irrigation facilities, Cengkilik Reservoir is the largest and it can irrigate around 750 hectares of 
rice fields. In Tasik Madu region, Kedung Ngunut Dam, Gembong Dam, Jongkang Dam, Lempung Dam, and Jumok Dam were built [10].

In addition to the importance of sugar cane planting, the irrigation network was also used for rice farming and settlements. The irrigation of farmers' rice fields associated with sugar cane plants was used alternately, because the management of rice fields between sugar factories and farmers used a rotary system or glebagan. In this system, rice fields were divided into two or three plots that were cultivated alternately between sugar factories and farmers for planting rice according to the age of sugar cane namely 18 months and the age of rice which is on average 6 months. The settlements in sugar factory area generally used the irrigation from those irrigation networks, whether that have been processed by the Surakarta Water Company, or not [4].

In line with the importance of staffs and factory workers, health facilities were also built within the sugar factories. Polyclinics in both sugar factories were built. In its development, the polyclinics also served the society around the sugar factories. Polyclinics are very important to provide treatment for various diseases that develop in the community, namely fever, cholera, smallpox, worms, and those that are endemic namely typhus. These various of diseases are generally associated with an unhealthy environment. Cholera developed into an epidemic in 1902, it was tried to be eradicated but in a few years later it spread again. In addition to the treatment for patients, prevention was also carried out through vaccination for residents who have not been affected by the epidemic.

The disease that develops due to poor environmental factors is pestilence disease. This type of disease has been growing rapidly since 1915 . The disease was actually originated from Solo which has infected by the disease because it passed through the railroad and tram. The settlements in the Mangkunegaran Sugar Factory area are also affected by the plague. From 1915 to 1929 in Colo Madu, there were 178 patients affected by pestilence disease. Meanwhile, there were 24 people around Tasik Madu infected. Local authorities have tried to overcome the spread of this disease with prevention and eradication. Prevention was carried out in various ways such as spraying with exterminating drugs in rat nests, disassembling houses that were indicated to be the occupancy of rats, and building new houses in other places. Meanwhile, the patients who have been infected, should receive medical treatment in the nearest polyclinic and hospital.

Other diseases caused by the environment is worm disease. This disease developed mainly in the Tasik Madu area. The habit of defecating in the plantation is one of the triggers. For this matter, the factories and the local government have conducted counseling, treatment, and building family toilets [4].

\section{Conclusion}

Based on the description above, it can be concluded that the Mangkunegaran Sugar Factory has established a new residential environment in the form of a satellite city of Sala City. These settlements followed the pattern of the development of the sugar industry with factories as the center. The settlements are followed by modern supporting facilities for society starting from highways, clean water, to means of communication. In line with the economic development of the factories, residential settlements are increasingly dense which impacts on environmental issues, including various kinds of diseases. The factories, together with the local government of 
Mangkunegaran, was trying to provide infrastructure and health facilities, including the polyclinic which was intended for both factory employees and the surrounding community.

\section{References}

[1] K. Tijdschrift, "Het en ander over het 'Pasar'of Marktwezen in de Gouvernementslanden op Java en Madoera", Uitgegeven door de Vereeneging van Ambtenaren bij het Binnenlandsch Bestuür in Nederlandsh Indië. 1913.

[2] S. Kartodirdjo and D. Surjo, Sejarah perkebunan di Indonesia: kajian sosial-ekonomi. Aditya Media, 1991.

[3] V. Houben, "Kraton and Kumpeni: Surakarta and Yogyakarta, 1830-1870. By Vincent JH Houben. Leiden: KITLV Press, 1994. vii, 396 pp. \$38.50,” J. Asian Stud., vol. 55, no. 3, pp. 782-784, 1996.

[4] Wasino, Kapitalisme bumi putra: perubahan masyarakat Mangkunegaran. LKiS, 2008.

[5] H. L. Wesseling, "Fasseur (C.): Kultuurstelsel en Koloniale Baten. De Nederlandse exploitatie van Java, 1840-1860," Outre-Mers. Rev. d'histoire, vol. 62, no. 229, pp. 716-718, 1975.

[6] A. K. Pringgodigdo, Geschiedenis der ondernemingen van het Mangoenagorosche rijk. Nijhoff, 1950.

[7] E. S. Hartatik, "The Development of Agroindustry and Transportational Network in the Central Java during Dutch Colonization," Paramita Hist. Stud. J., vol. 24, no. 1, 2014.

[8] Mansveld, Geschiedenis der Eigendommen van het Mangkoenegorosche Rijk. Surakarta: Koleksi Reksa Pustaka Mangkunegaran.

[9] Wasino, E. S. Hartatik, and Nawiyanto, "From royal family-based ownership to state business management: Mangkunegara's sugar industry in Java from the middle of the 19th to early 20th century," Manag. Organ. Hist., pp. 1-17, 2019.

[10] Overzicht der Belangrijkste Irrigatiewerken in het Mangkoenagarasche Gebied. dam bundel P 2479. Arsip Reksa Pustaka Mangkunegaran. 